\title{
LEVEL OF EDUCATION AND ENTREPRENUERIAL RISK ATTITUDES OF MARKET WOMEN IN LAGOS, NIGERIA
}

\section{DOI: $10.36108 /$ ljerhrm/2202.03.0191}

\author{
GENTY,Kabiru Ishola PhD \\ Lagos State University, Ojo Lagos Nigeria \\ Industrial Relations \& Human Resource Management Department ${ }^{1}$ \\ ishola.genty@lasu.edu.ng
}

\author{
AJEMUNIGBOHUN,Sunday Stephen PhD \\ Lagos State University, Ojo Lagos Nigeria \\ Insurance Department $^{2}$ \\ sunday.ajemunigbohun@lasu.edu.ng
}

and

ORESHILE,Ademola Sulaiman

Lagos State University, Ojo Lagos Nigeria

Insurance Department ${ }^{2}$

sulaiman.oreshile@lasu.edu.ng

\begin{abstract}
Every economy who intends to grow will never put women entrepreneurial drives and skills at the backspace as they serve as engine room for every prosperous economy. Nonetheless, female entrepreneurs lack most often the financial access and the right human capacity development, which impinge their business growth due to their various mindsets' drawbacks created by poor risk attitude. This study therefore is specifically aimed at evaluating the relationship between level of education and entrepreneurial risk attitudes with particular reference to market women in Lagos, Nigeria. The study adopted questionnaire as a source of data collection among 123 respondents, drawn from 15 purposive selected markets in Lagos, Nigeria. Correlation technique approach was adopted to explain the relationships between the measuring constructs in the study. The findings from the study revealed a not significant relationship between entrepreneurs' level of education and their entrepreneurial risk attitudes $(r=.080, p=.380>0.05)$. The study further established $a$ correlation between level of education and entrepreneurial risk attitudes dimensions (risk aversion, risk neutrality and risk preference) where no association exist between level of education and risk aversion ( $r=.154, p=.089>0.01)$. However, a strong positive and significant relationship were found between level of education and risk neutrality $(r=.526, p=.000<0.01)$ and risk preference $(r=.524, p=.000<0.01)$ respectively. The study conclusion showed that risk seeking behaviour is not moderated in the entrepreneurial pursuit of market women in Lagos State. The responses of the respondents largely proved that the level of education among market women hasn't created any form of risk consciousness. Thus, the researchers recommended that risk management education should be considered as a focal point in the development of the market women psychologically and sociologically to get attracted to insurance in order to manage possible entrepreneurial failure.
\end{abstract}

Keywords: Level of education, Entrepreneurial risk attitudes, Lagos, Market women \& Nigeria 


\section{Introduction}

The huge roles, tasks, responsibilities, and duties being assumed by women in modern family, communities, and at national level cannot be underestimated. Studies have shown that women with education, skills, and drives around the globe have energetic capacities as major contributors to both national and world economy (Alsos \& Ljunggren, 2017; Gimenez \& Calabro, 2018; GimenezJimenez, Edelman, Dawson, \& Calabro, 2020; Ozgen, 2012; Siba, 2019). Women have continued to display appreciable professionalism and tenacity to drive micro, small and medium enterprises in every facet of any nation's economy (Mozumdar, Hagelaar, Velde, \&Omta, 2020; Schiff, Fries, \& Chambers, 2013; Zhu, Kara, \& Zhu, 2019).

Every economy who intends to grow will never put women entrepreneurial drives and skills at the backspace as they serve as engine room for every prosperous economy. Nonetheless, female entrepreneurs lack most often the financial access and the right human capacity development, which impinge their business growth due to their various mindsets' drawbacks created by poor risk attitude (Siba, 2019). Risk attitudes of entrepreneurs have been said to affect their personality traits, hence this has influence on their decisions and desires to access funds and adequate training (Ajemunigbohun, Isimoya, \&Elegunde, 2020; Kerr, Kerr, \& Dalton, 2019). According to Araar, Awel, Boka, Girma, Shafi, Yitbarek, and Zerihum (2019), risks assumed by women in micro and small enterprises are at variance to that of men in their ownership and management of such business.

Growing literature (such as Abdieva, Sulaimanova, \&Karymshakov, 2019; Sepulveda \& Bonilla, 2014) have evaluated gender differences in relation to risk attitudes, and their resultant effects depending on their contextual environments. While earlier work of Beckman and Mankhoff (2008) noted no difference in both men and women in relation to insurance coverage against risks, but found women to be more conscious than men in investment. Bardasi, Sabarwal and Terrel (2009) evident risk consciousness more in women when it relates to credit facilities. Against this backdrop, women entrepreneurs can better improve their entrepreneurial skills and drives with proper educational qualifications in force.

Takawira (2020) argued that education has an integral part of the transformative process of the socioeconomic behaviour of mankind, as this will help the societies which have people with more entrepreneurial traits to advance economically as juxtaposed to those individuals with lesser numbers. Owusu-Ansah and Poku (2012) earlier noted that the competencies, capacities, and creativities-built overtime through education will help brace young individuals to confront challenges and ambiguities that pervade modern socio-economic milieus. This study therefore is specifically aimed at evaluating the relationship between level of education and entrepreneurial risk attitudes with particular reference to market women in Lagos, Nigeria.

\section{Literature Review}

\section{Entrepreneurs and Educational Qualifications}

Amanamah (2017) defines an entrepreneur as individual with creative ideas and who coordinates factors of production for the purpose of assuming all risks linked with successful business progress. Raguz and Matic (2011) earlier depicted an entrepreneur as a self-employed individual with initiatives, coordinating, and managerial abilities to man a business. According to Teshome (2014), 
entrepreneurship is an art of establishing and controlling an enterprising entity in a profitable manner. Entrepreneurship, as depicted by Mazura and Norasmah (2011) as cited in Rudhumbu, Svotwa, Munyanyiwa, and Mutsau (2016), is a long-term strategy for curtailing unemployment and enhancing economic development by exploring every available business opportunity. This long-term strategy is attainable in an economy with sound and sustainable educational skills for entrepreneurship entrepreneurs.

Education is crucial to national development. It is a significant instrument for sustainable development (Maina, 2013). Generally, education is being noted to have an impact on entrepreneurship (Karimi, Biemans, Lans, Chizari, \& Mulder, 2014). Education is a systematic and regulated method of transferring important knowledge from one generation to another (Alarcon, Navarrete, Bello, Montecino, Mardones, Gonzalo, \& Menezes, 2018). It gives an individual required skills and knowledge needed within a society and workforce to improve, enlighten and equip them to produce maximally. When you are educated, you have a greater chance of getting better employment, higher income and setting up a viable business (Teichler, 2018). Education is key to developing a well-informed and skillful individual who can contribute meaningfully to social and economic development (Ezema, Adegbuyi, Olokoyo, \& Okoh, 2021). However, successes in educational attainment helps in the entrepreneurial advancement of any business operator (Olokundun, Ibidunni, Peter, Amaihian, Moses, \&Iyiola, 2017). This, in essence, will create the necessary survival impetus to achieve impactful goals in many business activities (Aligba\& Fusch, 2017).

With the educational advancement of an individual entrepreneur, expected entrepreneurial traits and characters include inner locus of control, risk propensity, pursuits of achievement, self-confidence, tolerance of ambiguity and creativity shall be moulded (Frese \&Gielnik, 2014; Kiyani, 2017; Ljubotina, 2020). Meanwhile Herrington, Kew, and Kew (2009) ascribed self-confidence and development of individual entrepreneur in their business start-up and the furtherance of their learning skills in higher institutions to educational attainment. No wonder, Fauziah (2012) noted that the level of education helps dispirit individual entrepreneur from hunting for chances in the labour market, rather develops and improves their entrepreneurial mindsets, capacities, and competencies. Even with these decisions to enhancing their entrepreneurial capacities, entrepreneurs are faced with certain barriers which include insecurity of income, loan anxiety, inexperience, insufficiency in business ideas, corruption, stiff competition, and bureaucracy (Kiyani, 2017; Sandhu, Sidique, \& Raiz, 2011; Jain \& Ali, 2013). These barriers are risks being encountered in all entrepreneurial activities, while the tenacity to managing and upscaling the capacity and competency of an entrepreneur is reliance upon the deployment of right-thinking risk attitudes. Thus, this can be achieved via detailed entrepreneurship education system.

According to Mwasalwiba (2010) as cited in Aladejebi (2018), entrepreneurship education was started by Shigeru Fiji in 1938 at Kobe University in Japan. Due to the perceived importance of entrepreneurship, a number of studies around the world, over the years, have been conducted with a view to establishing the relevance of entrepreneurship education to national development. In this light, gender, as a critical component of socio-economic development of any nation, is key to driving the success of entrepreneurship development. The importance of female entrepreneurship for 
economic development is widely recognized. Numerous studies demonstrate the positive impact of female entrepreneurs on economic growth and development, as well as sustainable and durable peace (Cuberes\&Teignier 2015; Fetsch, Jackson, \& Wiens 2015; Lewis, Henry, Gatewood, \& Watson. 2014.; Woetzel et al. 2015). Moreover, economies characterized by high levels of female entrepreneurial activity are more resilient to financial crises and experience economic slowdowns less frequently (Global Entrepreneurship Research Association, 2017).

\section{Entrepreneurial Risk Attitudes}

Risk attitude is critical to the discussion of human elements. The attitude of an individual is crucial to the variability of situational events. Risk attitude is referred to a person's enlightenment towards seeking or being conscious of risk when making decisions on how to navigate in circumstances with uncertain outcome (Rosen, Tsai, \& Downs, 2005). Fadun (2013) opined that people's display of risk attitude affect every atom of any entrepreneurial activities, even when they pretend to be unaware of it. Studies (such as Adeleke, Olowokudejo, \&Ajemunigbohu, 2016; Filmina, \&Mayangsari, 2020; Nishat \& Nadeem, 2016) have affirmed that an individual's or enterprise's risk attitude is a function of the patronage for risk management instrument such as insurance. According to Hopkin (2017), risk attitude is an indication of an organisation's long-term view of risk. However, with the rightthinking risk attitude displayed genuinely in the entrepreneurial activities, the desirable organisational objectives are achievable in that it eases entrepreneurs' capacities to build sustainable risk management tools (Ajemunigbohun et al., 2020).

Saeidi, Sofian, Abdul Rasid, Saeidi, and Saeidi (2013) added that trust ought to be built overtime in achieving the required risk attitudes, and thus improved by sustaining efficient organisational risk management. However, the underlying features are risk preference (i.e., risk-taking, propensity or risk-seeking), and risk aversion (risk consciousness or risk avoidance) (Rohrman, 2004a; Rohrman, 2004b). It is reiterated that a highly preferred risk situation can stimulate a hazardous situation. Aumann (2017) takes a classical theory approach when he defined risk aversion as a behavioural attitude that recognises certainty equivalent of a situation as less than the situational expected value; .i.e. when an individual decision maker makes preference for single unit, which encompasses with certainty over situation of fairness among three units and none.

Risk preference is referred to as individual attitude person holds concerning risks, which is a core factor in financial decision-making behaviour (Wen, He \& Chen, 2014). People steadily observed that financial decision-making behaviour, in real life, does not hold in compliance with the presumption of rationality and then behaviours are often restricted by cognitive biases or nonobjective perception, and external milieu, leading to an individual risk seeking varying with diverse circumstances (Appelt, Milch, Handgraat, \& Weber, 2011). Psychologically, risk preference is delineated as the behavioural propensity to acclimate with rewarding outcomes of potential loss attributes (Steinberg, 2013). Economically, risk preferences are deemed as behavioural propensity involving greater variation in returns, despite either experiential gains or losses (Mata, Frey, Richter, Schupp, \& Hertwig, 2018). In short, risk preference is an individual's enlightenment regarding risktaking (Khanal, Mishra, \& Kumar, 2019). 


\section{Theoretical Review}

Planned behaviour, as a theory, was propounded to depict social values, attitude and controlled behaviour of mankind in business related activities (Zhang \& Cain, 2017). This theory commenced as the theory of reason action in the 80's to predict individuals' intents to get involved in behavioural events at a specific place and time (Ajzen, 2011). It is a well-designed estimates of risk attitude regarding a behaviour of interest, perceived behavioural intention and control, and subjective values. The outcome of previous studies (such as Carr\& Sequeira, 2007; Fayolle \&Gailly, 2004; Kautonen, Van Gelderen, \&Tornikoski, 2013) have shown that the theory of planned behaviour (TPB) has contributed extensively to entrepreneurial studies. This theory is thus considered typical for entrepreneurial activities even if the new venture may develop abruptly due to a chance realised.

With TPB, two major sources of intent, that is, motivation to act for an intended behaviour and possibility of a given behaviour (Sabah, 2016). It is necessary to note that TPB contends that intent is a direct antecedent of behavioural performance. TPB stipulates, in principle, that the more acceptable the attitude and subjective value, the higher the perceived behavioural control, the stronger an individual's intent concerning the performance of entrepreneurial behaviour (Moses, Olokundun, Akinbode, Agboola, \&Inelo, 2016).

\section{Review of the Empirical Studies}

Several studies have been conducted both in Nigeria and other countries of the globe to identify the relationship between entrepreneurship education and that of women risk attitudes (e.g. Awe \& Genty, 2017; Aladejebi, 2018; Boermanns\&Willebands, 2017; Filmina\&Mayangsari, 2020; Kerr et al., 2019; Nishat \& Nadeem, 2016) but these studies are inconclusive because of unstable findings.

Sepulveda and Bonilla (2014) conducted their study on the factors affecting risk attitude in entrepreneurship, with particular reference from Latin America. The study adopted cross country survey design with a sample size of 2000 individual entrepreneurs chosen at random. The study took note of countries like Argentina, Brazil, Chile, Mexico, and Venezuela. For data collection technique, an expert questionnaire was employed. The study data analytical comprised of descriptive statistics and multiple regression technique. The study established that being a woman increases the probability of feeling of fear, which sometimes consistent with previous studies concerning gender and risk aversion. Their results contravene the entrepreneurship literature that ae applied to developing countries, and therefore hypothesised that low level of trust and the weaknesses in institutions in Latin America generates a stigma effect that assists to explain their results.

Thus, Zurriiaga-Carda, Kageyama, and Akai (2016) research was based on the relationships between risk attitude, entrepreneurship education and self-efficacy and entrepreneurial intentions, with particular reference in structural equation model approach to entrepreneurship. While questionnaire survey instrument was employed among 264 participants, Structural Equation Approach was used in analysing collected data. The study stressed that future entrepreneurial behaviour can help forecast through entrepreneurial intentions. The study added that understanding which factors affect entrepreneurial intentions can assist improve the rate of entrepreneurship and as a result, affect country's risk propensity. 
Awe and Genty (2017) investigated the relationship between entrepreneurship education and training on business venturing among undergraduate students in Lagos State University that offered entrepreneurship. The study adopted instrument developed by Nian et al with Cronbach Alpha of 0.78 while the collected data were analysed descriptively and the stated research hypotheses were tested using Pearson's Product Moment Correlation analysis. The findings revealed that entrepreneurship education and training has encouraged students to pursue business venturing $(\mathrm{r}=$ $.619, \mathrm{p}<0.01)$. Similarly, the relationship between entrepreneurship education and training on innovations for commercialisation among the students was also significant $(r=.338, \mathrm{p}<0.01)$.

Kozubikova, Dvorsky, Cepel, and Balcerzak (2017) investigated the important characteristics of an entrepreneur in relation to risk taking, particularly in Czech Republic. The study further examined entrepreneurs' financial risk attitudes to their socio-demographic characteristics and their personality traits consisted of risk taking, decisiveness and optimism. While questionnaire survey technique was adopted among sample participants of 1141, descriptive statistics and T-test statistic were employed on collected data. The study results show that entrepreneurs attempted to reduce their financial risk by building up reserves in connection to such attributes as 'risk taking' and 'decisiveness' in juxtaposition to negative effects of optimism.

Khan, Sharma, and Thoudam (2019) assessed the relationship between the role of attitude and entrepreneurship education, with specific reference to entrepreneurial orientation among business students in Bhutan. The major theory employed in the study was the theory of reasoned action. While the study adopted questionnaire as a source of data collection among 253 respondents, correlation technique and regression analysis employed with SEM approach to explain the relationships between the measuring constructs in the study. The findings from the study revealed a significant effect of perception and attitude towards entrepreneurship orientation. The study further established a positive and significant correlation between entrepreneurship education and entrepreneurial orientation.

Takawira (2020) evaluated the relationship between entrepreneurship education and entrepreneurial goal intentions of entrepreneurs, with focus on their psychological traits as mediators. The study selected some psychological traits of entrepreneurs comprised of need for achievement, risk-taking propensity, and internal locus of control and mediated them of the perceived relationship between their entrepreneurship education and entrepreneurial intentions in Zimbabwe. The study adopted cross-sectional survey design with a sample size of 308 vocation education students. While questionnaire survey technique was employed, the study made use of SEM in the analysis to explain the relationships that subsist among the variables. The results from the study revealed that the need for achievement, risk-taking propensity, and internal locus of control were responsible for statistical significance in variance to entrepreneurial intentions. The findings further produced a positive and statistically significant relationship between the inherent components of the independent variables and the dependent variable, entrepreneurial intentions. Therefore, we hypothesized that:

Ho: There is no significant relationship between level of education and entrepreneurial risk attitude of market women in the Lagos, Nigeria. 


\section{Gap identified in the Literature}

Hsieh (2017) observes that if entrepreneurship assumes more precarious occupation than paid employment, and if there is variation in individual's risk aversion, it then indicates that the least riskaverse individuals are most likely to become the entrepreneurs. Veskovik (2014) thus observes that risks in entrepreneurship are normal circumstances that should be prepared for by an entrepreneur for organisational progress and success. Considering the numbers of existing literature investigated on level of education, and entrepreneurial risk attitude, there seems to be limited numbers of studies conducted in relation to market women. With the core importance of educational qualification, empirical studies among market women in Nigeria are rare, and then, appear not to have been extensively explored. This is a major gap in Nigeria which calls for intervention and part of which initiate this study. Furthermore, this study differs from existing studies in Nigeria, by examining women entrepreneurial risk attitudes in Nigeria.

\section{Research Methods}

This study adopted the use of survey design. The research design was employed because of its prediction ability and the quality of being able to obtain information about all sample cases (Heiberger \& Holland, 2017). Structured questionnaires were utilized to obtain information from the respondents which were drawn from a Likert scale measurement of 'Strongly Agree', 'Agree', 'Undecided', 'Disagree', and 'Strongly disagree'.

The research grounds for collection of data were selected markets situated within eleven (11) Local Government Council Areas and four (4) Local Council Development Areas chosen within Lagos State, Nigeria. The markets comprised of Mile-12 market (KOSOFE), Ojuwoye market (MUSHIN), Alaba International market (OJO), Aspanda market (AMUWO-ODOFIN), Ansuani market (ISOLO), Olaleye market (SHOMOLU), Tejuosho market (YABA), Badagry market (BADAGRY), Balogun market (LAGOS-ISLAND), Computer Village market (IKEJA), and Ajina market (IKORODU) all were markets in Local Government Areas (LGAs).

The Local Council Development Areas (LCDAs) markets are Itokin market (IKOSI-EJINRIN), Anjorin market (APAPA-IGANMU), Aguda market (COKER-AGUDA), and Abule market (BARIGA). The choice of these samples areas was due to their high population density and presence of more women gender for easy access by research assistants during the data gathering exercise. One hundred and fifty (150) copies of research instruments were purposively distributed proportionately at 10 copies per market for the 15 markets that were carefully selected for the study in Lagos State, Nigeria.

One hundred and twenty-four (124) copies of the questionnaires were retrieved after administration by the research assistants but 123 copies were found valid for analysis usage representing $82 \%$ rate. The study also takes cognizance of the validity of the research instrument using construct and content validity. For construct validity, well ground literatures were extensively used, while for the content validity, academia and field experts in areas such as business management, insurance and risk management as well as education scholars were consulted to check the drafted questionnaire before field administration. The instrument met the threshold of 0.726 , which implies it is above reliability value therefore, it can be used for further analysis. 
Collected data were analyzed descriptively and inferentially using Statistical Package for Social Sciences (SPSS Version 24.). The bio-data variables were analyzed with descriptive statistics such as frequency table, percentage, mean and standard deviation while the formulated research hypothesis was tested with inferential statistical tools called Pearson's product moment correlation analysis.

\section{DATA ANALYSIS AND RESULTS}

\section{Analysis of Respondents Bio-Data}

Table 1 below revealed the bio-data of the respondents, where the age bracket of the respondent has a mean of 2.18 and standard deviation of 1.071. Respondents with less than 30 years of age were 42 (34.1\%), while respondents between the age bracket of 30 years but less than 40 years were 35 (28.5\%), those that belong to 40 years but less than 50 years were $29(23.6 \%)$ and respondents of 50 years of age but less than 60 years were $16(13 \%)$ while 60 years and above was $1(8 \%)$. This indicates majority of the respondents belong to the age bracket of less than 30 years, meaning the market women in Lagos State, Nigeria was in their youthful age.

Marital status of the respondents was within the mean value of 1.78 and standard deviation of 0.608 . Single among the respondents were 39 (31.7\%) while married respondents were $72(58.5 \%)$ meanwhile $12(9.8 \%)$ were divorced respondents. This depicts that majority of the respondents were married and it can be attributed to the nature of their businesses. The educational qualifications of the respondents were also analysed and it revealed that the mean value was 1.98 and standard deviation was 1.008. Those with WAEC/SSCE were 53 (43.1\%), OND/NCE holders were 29 (23.6\%) while respondents with BSC/HND were $31(25.2 \%)$ and respondents without western educational qualifications were $10(8.1 \%)$. It shows that majority of the respondents hold WAEC/SSCE and this can be linked to marketing activities that the respondents do which might not necessarily need serious western educational background.

This study also analysed the bio-data of the respondents from the perspective of number of branches operation that the respondents have and it revealed that the mean value of the branches was 1.59 with standard deviation of 0.819 . Respondents with less than 5 branches were $77(62.6 \%)$, those with less than 10 branches were 20 (16.3\%) while respondents with less than 20 branches were $20(21.1 \%)$. This indicates that majority of the respondents have more than 5 branches. 
Table 1: Analysis of Respondents Bio-Data

\begin{tabular}{|c|c|c|c|c|c|}
\hline Variables & Categories & Frequency & Percentage & Mean & $\begin{array}{l}\text { Standard } \\
\text { Deviation }\end{array}$ \\
\hline \multirow[t]{6}{*}{ Age } & & & & 2.18 & 1.071 \\
\hline & Less than 30 years & 42 & 34.1 & & \\
\hline & 30 years but less than 40 years & 35 & 28.5 & & \\
\hline & 40 years but less than 50 years & 29 & 23.6 & & \\
\hline & 50 years but less than 60 years & 16 & 13 & & \\
\hline & 60 years and above & 1 & 8 & & \\
\hline \multirow[t]{4}{*}{ Marital Status } & & & & 1.78 & 0.608 \\
\hline & Single & 39 & 31.7 & & \\
\hline & Married & 72 & 58.5 & & \\
\hline & Divorced & 12 & 9.8 & & \\
\hline \multirow{5}{*}{$\begin{array}{l}\text { Educational } \\
\text { Qualifications }\end{array}$} & & & & 1.98 & 1.008 \\
\hline & WAEC/SSCE & 53 & 43.1 & & \\
\hline & OND/NCE & 29 & 23.6 & & \\
\hline & BSC/HND & 31 & 25.2 & & \\
\hline & None & 10 & 8.1 & & \\
\hline \multirow[t]{4}{*}{ Branches } & & & & 1.59 & 0.819 \\
\hline & Less than 5 & 77 & 62.6 & & \\
\hline & Less than 10 & 20 & 16.3 & & \\
\hline & Less than 20 & 26 & 21.1 & & \\
\hline
\end{tabular}

Source: Researcher, 2021

\section{Testing of Research Hypothesis}

$\mathrm{H}_{0}$ : There is no significant relationship between Level of Education and Entrepreneurial Risk Attitudes among market women in Lagos State, Nigeria.

Table 2: $\quad$ Results of bi-variate correlation between level of education and entrepreneurial risk attitudes with descriptive analysis

\begin{tabular}{llccccc}
\hline & Variables & $\mathbf{N}$ & Means & Std. Deviation & $\boldsymbol{r}$ & $\boldsymbol{p}$ \\
\hline 1 & Level of education & 123 & 1.89 & 1.008 & & \\
2 & Entrepreneurial risk attitudes & 123 & 2.86 & .943 & .080 & .38 \\
\hline
\end{tabular}

** $p$ is significant at 0.05 level (2-tailed) 
Table 2 above showed that the level of education does not have significant relationship with entrepreneurial risk attitudes in this study because the $\mathrm{p}$ value is greater than 0.05 while the correlation value is .080 . It shows that there is no significant relationship between level of education and entrepreneurial risk-taking attitudes. Thus, the study does not support the findings ofZurriiaga-Carda, Kageyama and Akai (2016); Awe and Genty (2017) who investigated the relationship between education and entrepreneurial outcomes such as risk attitudes, self-confidence, business venturing and entrepreneurial intentions.

To further proved this finding, a canonical correlation analysis was used with the aid of dummy coding for each of the entrepreneurial risk attitudes subdimensions (risk aversion, risk neutrality, risk preference) which served as the dependent variable on the level of educational attainment of the participants as the independent variable. The correlation test results are presented in Tables 3 below.

Table 3: Canonical Correlations analysis of the significant relationship between Level of Education and Entrepreneurial Risk Attitudes

\begin{tabular}{|c|c|c|c|c|c|}
\hline & & $\begin{array}{c}\text { Indicate } \\
\text { your } \\
\text { educational } \\
\text { qualificatio } \\
\text { n }\end{array}$ & $\begin{array}{c}\text { Risk } \\
\text { Aversion }\end{array}$ & $\begin{array}{c}\text { Risk } \\
\text { Neutrality }\end{array}$ & $\begin{array}{c}\text { Risk } \\
\text { Preference }\end{array}$ \\
\hline \multirow{4}{*}{$\begin{array}{l}\text { Indicate your } \\
\text { educational } \\
\text { qualification }\end{array}$} & Pearson & 1 & .154 & .094 & -.061 \\
\hline & Correlation & & & & \\
\hline & Sig. (2-tailed) & & .089 & .302 & .503 \\
\hline & $\mathrm{N}$ & 123 & 123 & 123 & 123 \\
\hline \multirow[t]{4}{*}{ Risk Aversion } & Pearson & .154 & 1 & $.526^{* *}$ & $.327^{* *}$ \\
\hline & Correlation & & & & \\
\hline & Sig. (2-tailed) & .089 & & .000 & .000 \\
\hline & $\mathrm{N}$ & 123 & 123 & 123 & 123 \\
\hline \multirow[t]{4}{*}{ Risk Neutrality } & Pearson & .094 & $.526^{* *}$ & 1 & $.524^{* *}$ \\
\hline & Correlation & & & & \\
\hline & Sig. (2-tailed) & .302 & .000 & & .000 \\
\hline & $\mathrm{N}$ & 123 & 123 & 123 & 123 \\
\hline \multirow[t]{4}{*}{ Risk Preference } & Pearson & -.061 & $.327^{* *}$ & $.524^{* *}$ & 1 \\
\hline & Correlation & & & & \\
\hline & Sig. (2-tailed) & .503 & .000 & .000 & \\
\hline & $\mathrm{N}$ & 123 & 123 & 123 & 123 \\
\hline
\end{tabular}

Table 3 above showed that the level of education of the entrepreneurs does stimulate their risk aversion $(\mathrm{p}>.01, \mathrm{r}=.154)$. Therefore, there is no correlation between level of education and the entrepreneurial risk aversion. This finding contract Kozubikova, Dvorsky, Cepel, and Balcerzak (2017) result on the relationship between entrepreneurial education and risk taking in Czech 
Republic. However, in the study it was established that the level of education and entrepreneurial risk neutrality was significant at $\mathrm{p}<.000$ and $\mathrm{r}=.526$. This is an indication that the level of education of the entrepreneurs is a determinant of their risk neutrality. Thus, the finding is in tandem with the work of Aumann (2017) on entrepreneurship education and risk-taking attitudes where the scholar augured that highly preferred risk situation can stimulate a hazardous situation, therefore educated entrepreneurs have to be neutral to such risk.

Similarly, there is a positive significant relationship between level of education and entrepreneurial risk preferences because the $\mathrm{p}$ value is less than $0.01(\mathrm{p}=.000, \mathrm{r}=.524)$. This depicts a strong positive relationship exist between level of education and risk preferences among the market women entrepreneurs in Lagos State, Nigeria. The findings have a credence in the work of Khanal, Mishra and Kumar (2019). In short, risk preference is an individual's enlightenment regarding risk-taking, therefore, with the level of education, entrepreneurs are cautious of the kind of risk to indulge.

\section{Conclusion and Recommendations}

From the empirical analyses conducted and the test of hypotheses carried out, this study has been able to address the research objectives. The results confirmed that the level of education among market women in Lagos State indicated risk preference entrepreneurial behaviour, leading to the rejection of all null hypotheses at 0.05 level of significance. The findings showed that risk seeking behaviour is not moderated in the entrepreneurial pursuit of market women in Lagos State. The responses of the respondents largely proved that the level of education among market women hasn't created any form of risk consciousness. The study further showed that with the level of education of market women in Lagos State, their entrepreneurial risk level is high hence no significant relationship as produced in the analytical outcomes.

Based on the justification adduced to in this study, the researchers recommended that risk management education should be considered a focal point in the development ofthe market women psychologically and sociologicallyto get attracted to insurance in order to manage possible entrepreneurial failure. Enlightenment programmes should be carried out among market women to enable them to be aware that risk management experts, which includes insurers, as ideal experts to adequately assess existing risk management systems and help them to better priced their credit and other financial risk.

Acknowlgedment: This research was fully sponsored and financed by Tertiary Education Trust Fund (TETfund) under Institution-Based Research Intervention (IBR), therefore, the researchers really appreciate the board of TETfund for these wonderful supports in carrying out the research.

\section{References}

Abdieva, R., Sulaimanova, B., and Karymshakov, K. (2019). Gender differences, risk attitudes and entrepreneurship in Kyrgyzstan. Economics and Business Letters, 8 (1), 17-30. 
Adeleke, I.A., Olowokudejo, F.F., and Ajemunigbohun, S.S. (2016). Hazard perception and demand for insurance among selected motorcyclists in Lagos, Nigeria. The South East Asian Journal of Management, 10 (2), 121-140.

Ajemunigbohun, S.S., Isimoya, O.A., and Elegunde, A.F. (2020). Risk attitude, insurance patronage, and SMEs performance: Empirical evidence from Lagos, Nigeria. Annals of 'Dunarea de Jos' University of Galati, 26 (2), 70-78.

Ajzen, I. (2011). The theory of planned behaviour: reactions and reflections. Psychology and Health, 26 (9), 1113-1127.

Aladejebi, O. (2018). The effect of entrepreneurship education on entrepreneurial intention among tertiary institutions in Nigeria. Journal of Small Business and Entrepreneurship Development, 5 (2), 1-14.

Alarcon, J., Navarrete, L., Bello, P., Montecino, R., Mardones, N., Gonzalo, J.B., and Menezes, M. (2018). Integrating design-based learning methodologies in rural educational environments in Chile: A positive collaborative model at the head of the action. Proceedings of ICERI Conference, November 12 - 14, Seville, Spain.

Aligba, A.O., and Fusch, G.E. (2017). Entrepreneurial motivations and characteristics of Niger Delta youths: An exploratory study. Journal of Social Change, 9 (1), 87-99

Alsos, G.A., and Ljunggren, E. (2017). The role of gender in entrepreneur-investor relationship: A signaling theory approach. Entrepreneurship Theory and Practice, 41 (4), 567-590.

Amanamah, R.B. (2017). Tertiary students' attitude towards entrepreneurship education in Ghana. Journal of Small Business and Entrepreneurship Development, 5 (2), 125 - 133.

Applet, K.C., Milch, K.F., Handgraat, M.J., and Weber, E.U. (2011). The decision-making individual differences inventory and guidelines for the study of individual differences in judgment and decision-making research. Judgment and Decision Making, 6 (3), 252-262.

Araar, A., Awel, Y., Boka, J., Girma, H., Shafi, A., Yitbarek, E., and Zerihun, M. (2019). Entrepreneurs' attitudes toward risk in micro and small enterprises: Evidence from Urban Ethiopia. Working paper, Partnership for Economic Policy, February.

Aumann, Y. (2017). A conceptual foundation for the theory of risk aversion. Working Paper, 1- 45.

Awe, K.O and Genty, K.I. (2017). Entrepreneurship education and training on business venturing: Perception of Lagos State University undergraduate students. International Journal of Development Strategies in Humanities, Management and Social Sciences, 7(1), 1-11

Bardasi, E., Sabarwal, S., and Terrel, K. (2011). How do female entrepreneurs perform? Evidence from three developing regions. Small Business Economics, 37 (4), 417-423.

Beckmann, D., and Menkhoff, L. (2008). Will women be women? Analysing the gender difference among financial experts. Kyklos, 61 (3), 364-384.

Boermans, M., and Williebrands, D. (2017). Entrepreneurship, risk perception and firm performance. International Journal of Entrepreneurship and Small Business, 31 (4), 557565.

Carr, J. C., and Sequeira, J. M. (2007). Prior family business exposure as intergenerational influence and entrepreneurial intent: a theory of planned behavior approach. Journal of Business Research, 60 (10), 1090-1098. 
Cuberes, D., and Teignier, M. (2015). Aggregate Effects of Gender Gaps in the Labor Market: A Quantitative Estimate. Economics Working Paper E14/308, University of Barcelona, Barcelona. http://www.marcteignier.com/research_files/GGLMAP_CT.pdf.

Ezema, M., Adegbuyi, O., Olokoyo, F., and Okoh, E. (2021). Educational qualifications, entrepreneurial stimulation and start-ups in Nigeria. Proceedings of INTCESS, $8^{\text {th }}$ International Conference in Education and Education of Social Science, 18-19 January.

Fadun, S.O. (2013). Risk management and risk management failure: Lessons for business enterprise. International Journal of Academic Research in Business and Social Sciences, 3 (2), 225-239.

Fauziah, W.Y. (2012). Entrepreneurship development programme in higher learning institution: A case study of UniversitiTun Hussein Onn Malaysia, Proceedings of the International Conference of Technology Management, Business, and Entrepreneurship, Malaysia.

Fayolle, A., and Gailly, B. (2004). Using the theory of planned behaviour to assess entrepreneurial teaching programs: A first examination. $14^{\text {th }}$ Annual International Entrepreneurship Conference, University of Napoli Federico, Italy, $4^{\text {th }}-7^{\text {th }}$ July.

Fetsch, E., Jackson, C. and Wiens, J. (2015). Women Entrepreneurs are Key to Accelerating Growth. Kauffman Foundation. July 20. http://www.kauffman.org/what-wedo/resources/entrepreneurshippolicy-digest/women-entrepreneurs-are-key-to-acceleratinggrowth.

Filmina, A., and Mayangsari, L. (2020). The influence of risk attitude towards the entrepreneurial intention. International Conference on Economics, Business, and Economic Education 2019, KnE Social Science, 555-565.

Frese, M., andGielnik, M.M. (2014). The psychology of entrepreneurship. Annual Review of Organisational Psychology and Organisational Behaviour, 1, 413-438.

Genty, K.I; Ajemunigbohun, S.S. andOreshile, A.S. (2020). Religiosity and entrepreneurial risk attitudes among market women in Lagos, Nigeria. LASU Journal of Religions and Peace Studies, 4(3), 21-37

Gimenez, D., and Calabro, A. (2018). The salient role of institutions in women's entrepreneurship: A critical review and agenda for future research. International Entrepreneurship and Management Journal, 14 (4), 857-882.

Gimenez-Jimenez, D., Edelman, L.F., Dawson, A., and Calabro, A. (2020). Women entrepreneurs' progress in the venturing process: The impact of risk aversion and culture. Journal of Small Business and Economics, 21 (11), 1-22.

Global Entrepreneurship Research Association. (2017). The 2015/2016 Global Entrepreneurship Monitor. London: Global Entrepreneurship Research Association. http://www.gemconsortium.org/report.

Heiberger, R.M.and Holland, B. (2017). Statistical analysis and data display: An intermediate course with examples in regression. Journal of Statistical Software, 76(2), 1-6.

Herrington, M., Kew, J., and Kew, P. (2009). Tracking entrepreneurship in South Africa: A GEM perspective. Retrieved from http//www.gemconsrtium.org/article. Accessed $17^{\text {th }}$ November, 2021. 
Hopkins, P. (2017). Fundamentals of risk management: Understanding, evaluating, and implementing effective risk management. $4^{\text {th }}$ ed. Great Britain: Kogan Page Limited.

Hsieh, C., Parker, S.C., and van Praag, C.M. (2017). Risk, balanced skills, and entrepreneurship. Small Business, and Economics, 48, 287-302.

Jain, R., and Ali, S.W. (2013). A review of facilitators, barriers, and gateways to entrepreneurship: Directions for future research. South Asian Journal of Management, 20 (3), 17 - 25.

Karimi, S., Biemans, H. J. A. Lans, T. Chizari, M and Mulder, M. (2014). Effects of role models and gender on students' entrepreneurial intentions. European Journal of Training and

Development 38(8), 1-15

Kautonen, T., Van Gelderen, M., and Tornikoski, E. T. 2013. Predicting entrepreneurial behaviour: a test of the theory of planned behaviour. Applied Economics, 45 (6), 697-707.

Kerr, S.P., Kerr, W.R., and Dalton, M. (2019). Risk attitudes and personality traits of entrepreneurs and venture team members. ANAN, 116 (36), 17712-17716.

Khan, S.A., Sharma, P.P., and Thoudam, P. (2019). Role of attitude and entrepreneurship education towards entrepreneurial orientation among business students of Bhutan. International Journal of Recent Technology and Engineering, 8 (3), 335-342.

Khanal, A.R., Mishra, A.K., and Kumar, A. (2019). Risk preference and adoption of risk management strategies: Evidence from high-value crop production in emerging economy. Paper presented at the 2019 Agricultural and Applied Economics Association Annual Meeting, Atlanta, Jul, 21-23.

Kiyani, S.A. (2017). Role of entrepreneurship education on student attitudes.Abasyn Journal of Social Sciences, 10 (2), 270-292.

Kozubikova, L., Dvorsky, J., Cepel, M., and Balcerzak, A.P. (2017). Important characteristics of an entrepreneur in relation to risk taking: Czech Republic case study. Journal of International Studies, 10 (3), 220 - 233.

Lewis, K. V., C. Henry, E. J. Gatewood, and J. Watson. (2014). Women's Entrepreneurship in the

21st Century: An International Multi-Level Research Analysis. Cheltenham: Edward Elgar Publishing

Ljubotina, P. (2020). The influence of entrepreneurial skills, education, and risk perception in career choice intent: The case of European students with family business background. RSC, $12(11), 23-37$.

Maina, S. (2013). The role of entrepreneurship education on job creation among youths in Nigeria. International Letters of Social and Humanistic Sciences, 15, 87-96. Retrieved from www.creativecommons.org

Mata, R., Frey, R., Richter, D., Schupp, J., and Hertwig, R. (2018). Risk preference: A view from psychology. Journal of EconomicPerspectives, 23 (2), 155-172

Moses, C.L., Olokundun, M.A., Akinbode, M., Agboola, M., and Inelo, F. (2016). Entrepreneurship education and entrepreneurial intentions: The moderating role of Passion. The Social Sciences, 11 (5), 645-653.

Mozumdar, L., Hagelaar, G., Velde, G.V., and Omta, S.W.E. (2020). Determinants of the business performance of women entrepreneurs in the developing world context. Multidisciplinary Scientific Journal, 3, 215-235. 
Nishat, M., and Nadeem, J. (2016). Factors explaining the risk attitude towards entrepreneurship in Pakistan: An exploratory analysis. The Pakistan Development Review, 55 (4), 715 - 723.

Olokundun, M.A., Ibidunni, A.S., Peter, F., Amaihian, A.B. Moses, C.L., and Iyiola, O.O. (2017). Experiential pedagogy and shared vision: A focus on identification of business opportunities by Nigerian University Students. Journal of Entrepreneurship Education, 2 (22), 1-12.

Owusu-Ansah, W., and Poku, K. (2012). Entrepreneurship education, a panacea to graduate unemployment in Ghana. Journal of Humanities and Social Science, 2 (16), 211-220.

Ozgen, E. (2012). The effect of national culture on female entrepreneurial activities in emerging countries: An application of the global project cultural dimensions. International Journal of Entrepreneurship, 16 (1), 69-92.

Raguz, I.V., and Matic, M. (2011). Student's perception and intentions towards entrepreneurship: The empirical findings from the university of Dubrovnik-Croatia. International Journal of Management Cases, 12, 38-49.

Rohrman, B. (2004a). Project RS-Risk attitude scales (Research report). Melbourne: University of Melbourne, retrieved from www.rohrmannresearch.net/rac-report.pdf

Rohrman, B. (2004b). Technological versus socio-psychological risk management. In emergencymanagement-Australia (EMA) (Ed), safer sustainable communities. Proceedings of the 2003 Australia Disaster Conference, Canberra: EMA.

Rosen, A.B., Tsai, J.S., and Downs, S.M. (2003). Variations in risk attitudes across race, gender, and education. Medical Decision Making, 23 (16), 511-517.

Sabah, S. (2016). Entrepreneurial intention: Theory of planned behaviour and the moderation effect of start-up experience. INTECH, 88-101.

Saeidi, P., Sofian, S., Abdul Rasid, S.Z., Saeidi, P., and Saeidi, S.P. (2013). The role of trust in enterprise risk management. International Journal of Business and Behavioural Science, 3 (2), $17-25$.

Sandhu, M.S., Sidique, S.F., and Riaz, S. (2011). Entrepreneurship barriers and entrepreneurial inclination among Malaysian postgraduate students. International Journal of Entrepreneurial Behaviour and Research, 17 (4), 428 - 449.

Schiff, H., Fries, R., and Chambers, T. (2013). Beyond the threshold: Investing in women-led small and growing business. Mexico: Aspen Network of Development Entrepreneurs, Cherie Blair Foundation for Women, Bid Network and ING Bank Sustainability.

Sepulveda, J.P., and Bonilla, C.A. (2014). The factors affecting the risk attitudes in entrepreneurship: Evidence from Latin America. Applied Economics Letters, 21 (8), 573 581.

Siba, E. (2019). Empowering women entrepreneurs in developing countries: Why current programs fall short. African Growth Initiative, Policy Brief, February.

Steinberg, L. (2013). The influence of neuroscience on US Supreme Court decisions about adolescents' criminal culpability. Nature Reviews: Neuroscience, 14 (7), 513-518

Takawira, M.N. (2020). Relationship between entrepreneurship education and entrepreneurial goal intentions: Psychological traits as mediators. Journal of Innovation and Entrepreneurship, $9(2), 1-20$. 
Teichler, U. (2018). Higher education and graduate employment: Changing conditions and challenges. Working paper no. 10, International Centre for Higher Education Research, Kassel.

Teshome, T. (2014). Attitude of private higher education students towards entrepreneurship: A case of distance learners in Wolaitasodo and Hossana Towns. Middle-East Journal of Scientific Research, 19 (2), 277-285.

Veskovic, N. (2014). Aspects of entrepreneurial risks. Finiz, 115-117.

Wen, F., He, Z., and Chen, X. (2014). Investors' risk preference characteristics and conditional skewness. Mathematical Problems in Engineering, 1-14

Woetzel, J., A. Madgavkar, K. Ellingrud, E. Labaye, S. Devillard, E. Kutcher, J. Manyika, R. Dobbs, and M. Krishnan. (2015). The Power of Parity: How Advancing Women's Equality Can Add $\$ 12$ Trillion to Global Growth. Washington, DC: McKinsey \& Co.

Zhang, P, and Cain, K.W. (2017). Reassessing the link between risk aversion and entrepreneurial intention: The mediating role of the determinants of planned behaviour. International Journal of Entrepreneurial Behaviour and Research, 23 (5), 793 - 811.

Zhu, L., Kara, O., and Zhu, K. (2019). A comparative study of women entrepreneurship in transitional economies. Journal of Entrepreneurship and Emerging Economics, 11, 66-80.

Zurriaga-Carda, A., Kageyama, K., and Akai, K. (2016). Effects of risk attitude, entrepreneurship education and self-efficacy on entrepreneurial intentions: A structural equation model approach to entrepreneurship. International Review of Management and Business Research, 5 (4), $1424-1433$. 